\title{
CPQ Gene
}

National Cancer Institute

\section{Source}

National Cancer Institute. CPQ Gene. NCI Thesaurus. Code C92655.

This gene plays a role in the hydrolysis of proteins and peptides. 